\title{
NEGOTIATING THE PATH OF FAME: TRADITION AND MODERNITY IN THE PUBLIC PERSONA OF ROEKIAH (1917-1945)
}

\author{
Christopher Allen Woodrich \\ International Indonesia Forum/ Gadjah Mada University \\ chris_woodrich@hotmail.com \\ DOI: https://doi.org/10.24071/ijhs.2017.010102 \\ received 4 July 2016; revised 6 April 2017; accepted 10 July 2017
}

\begin{abstract}
The first great dame of the Indonesian cinema, Roekiah, rose to fame just as the medium of film came into its own. Born in 1917, she, as with many of her contemporaries, had a background in stage and was renowned for her vocal abilities. Her first filmic role, in Albert Balink's Terang Boelan (1937), catapulted her to stardom. Over the next five years she appeared in a further eight films, first opposite Rd. Mochtar then Ismail Djoemala, becoming one of the colony's bestloved stars. In her personal life, Roekiah was married to Kartolo, and would often defer to him when speaking to reporters. The couple had five children. This paper examines how the damsel-in-distress roles played by Roekiah and her public persona as a demure and obedient wife positioned her between two ideals: the traditional woman and the modern woman. It argues that, by negotiating between these two ideals and emphasizing her traditional attributes, Roekiah was able to capitalize on the patriarchal society's views of women, thus enabling her to reach a level of success unattained by such contemporary actresses as Fifi Young, Hadidjah, and Ratna Asmara.
\end{abstract}

Keywords: tradition, modernity, Roekiah, public persona

\section{Introduction}

One's identity is not monolithic, but best described as a grouping of identities, multiple understandings of the self which are manifested in different contexts. These can include, but are not limited to, sexual identities, gender identities, societal identities, and personal identities, all of which are given a varying degree of emphasis depending on contextual necessities. One individual, for instance, may be identified as a teacher while at school, a husband and father at home, a customer at a shop, a client at an office, a motorcyclist on the road, and a student at a tai-chi center. These identities bring with them their own rights and obligations, which are enjoyed and practiced as required by the social context.

In performance media such as the cinema, performers have an additional layer of identities through the characters they portray. In more extreme cases, these "assumed" identities are imprinted by the audiences onto performers; actors and actresses are identified with and defined by their characters' traits. As such, persons known for playing villains may be greeted with hostility when in public, 
and those who portray pitiful or sorrowful characters may receive offers of assistance. Less severely, actors and actresses may be identified with certain character types - as having a certain set of traits - from repeatedly taking similar roles, even if the actors themselves do not have such personalities. Even where this does not affect performers' personal lives, such typecasting drastically limits their opportunities for professional development, and as such is avoided when possible.

Based on the above discussion, it is necessary for individuals - particularly public figures - to manage their identities and thus present a certain public persona, one which may differ from their private persona. For those in the public sphere, a poorly managed public persona can be disastrous, and failure to hide identities considered improper by general society can potentially lead to ostracism and the end of one's career. However, if their public identities are properly managed, such individuals can gain enough popular support to rise to unrivalled levels of success. Such an experience was had by Roekiah, the first grand dame of Indonesian cinema.

This paper explores the public persona created by Roekiah in its relation to the "modern" and "traditional" ideals held by her audiences, who were mostly lower-class native Indonesian filmgoers. It argues that, by negotiating between modern and traditional ideals in her public persona, both through the characters she portrayed and her press appearances, Roekiah was able to find wide acceptance in the society of the Dutch East Indies, reaching levels of popularity which had never been seen before and thus cementing her cinematic legacy.

To support this argument, this article uses library research and a historical method to descriptively trace both Roekiah's life as well as her public portrayal. It is divided into five sections. Following this introduction, this article provides background on the cinema of the Dutch East Indies (modern-day Indonesia), with particular emphasis on the position of modernity and tradition. It then provides a biography of Roekiah, drawing on both contemporary sources as well as materials published after her death, before segueing into discussion of how Roekiah was depicted in film and in the popular press. This article closes by drawing some conclusions about Roekiah's negotiation of tradition and modernity and its contribution to her celebrity.

\section{Theory}

At the turn of the twentieth century, as the cinema was entering the Dutch East Indies, the colony was in a state of flux. The strict traditional systems of the indigenous and migrant ethnic groups in the colony, who were forced into a fixed hierarchy (and its corresponding cultural symbols) by colonial law, began to lose power after the Dutch enacted the Ethical Policy in the 1900s. As the colonies' laws began to liberalize and the colony's society increasingly urbanized, the nobility - holders of great power traditional power - began to receive a greater degree of Europeanized education. Through this education, these men and women learned not only factual information, but internalized (to varying degrees) European values which were not always in-line with traditional ones. Though for the common individual - particularly those in the lower class, who had little access to education - the relative positions of modernity and tradition were of little import, for the intelligentsia it was one of the colony's foremost issues. 
When these educated nobles began to play a role in national discourse, European culture was identified as modern culture, whereas the culture held by the different indigenous ethnic groups in the Indies was identified as Eastern. Owing in part to its highly political nature, discussion of the proper balance between the two drew heated polemics from both sides. In general, proponents of European culture argued that it offered greater fluidity and the possibility for development than traditional culture, which they considered to be too stagnant to serve as the basis for a new, independent country. Meanwhile, proponents of Eastern culture disapproved of the individualistic and secular "modernity", preferring instead traditional communalism and spirituality. Such cultural debates continued among the intellectual elite through the 1930s and until the Japanese occupation of the colony in 1942.

The fledgling colonial film industry was not immune to this discourse. It exhibited an extraordinary degree of dualism, of negotiation between tradition and modernity, in its stories, production practices, and treatment of performers. Traditional stories, particularly those already popular on the stage, were a staple of the early Indies cinema. The first domestic film was based on a frequently staged legend, Loetoeng Kasaroeng (1926). Popular stories from lenong, a semitraditional form of theatre in Batavia, were likewise adapted to film, including the bandit films Si Ronda (1930) and Si Pitoeng (1931). Even the novels adapted to film were those which had previously been brought to the stage (Author, 2014). During the first decade of Indies cinema, films based on original stories - such as Resia Boroboedoer (1928) - were the exception, rather than the norm.

Production aspects likewise contributed to this duality between tradition and Westernized modernity in the cinema. In the earliest productions, films' directors and producers were the same individuals, and retained total control over a production. The director/producer likely provided oral guidance to actors and actresses - most of whom were illiterate - during rehearsals (Author, 2014); no shooting scripts were not used until Njai Dasima in 1932. Interior scenes in these films were shot on fixed set-pieces and from angles similar to what one would see on stage, while beautiful landscapes were a favourite for exterior scenes. The latter took advantage of the camera's portability, lending the medium unprecedented potential to present a variety of breathtaking locations.

As with the traditional stage, the early Indies cinema gave individual performers less emphasis than the performance itself. Advertisements for early productions, such as Loetoeng Kasaroeng and Eulis Atjih (1927), emphasized the technical achievement of producing a film locally. The former boasted itself as the "First Showing of the First Netherlands Indies Film," original Eerste vertooningen van de Eerste Ned. Indie Speel Film (Biran, 2009), while the later claimed to be a "FILM OF THE TIME OF PROGRESS," original FILM DJAMAN KEMADJOEAN (Biran, 2009). With the advent of the talkie in the Indies in the early 1930s, the technical aspects of films became their key selling point. With Indonesia Malaise (1931), for instance, Halimoen Film offered audiences a clear listening experience or their money back, while Tan's Film plugged their second adaptation of Njai Dasima (1932) as a "Speaking - Singing - Dancing and Musical Talkie"; all aspects which prioritized the technical abilities available with the advent of sound (De Indische Courant 1932). 
Reviews were similar in their lack of discussion of named individuals. For instance, in Kwee Tek Hoay's discussion of such films as Njai Dasima (1929) and Melati van Agam (1930/31), he refers to actors as "the one holding the role of Dasima" or "the one who is Edward," original "jang pegang rol Dasima" and "jang djadi Edward" (Kwee, 1929), or avoids discussing them altogether, mentioning only their characters (Kwee, 1930). In his reviews, it is the roles that actors fill, and the quality of their performances, which must be identified and discussed. The actors themselves, as individuals, are of little concern, and Kwee firmly rejects the idea that a single performer can save a poor production, writing "bad meat, lacking in spices, cannot be made delicious just by adding Worcester sauce, [and] an actress cannot make a film's plot interesting if it's been misdirected, shot poorly, and everything else is chaos" (Kwee, 1929). Technical aspects of the productions, though not positioned as centrally as in advertising, were never left out of reviews.

For the first decade Indies cinema, there was a simultaneous emphasis of technical marvels and progress - the modernity of the cinema - and marginalization of the (predominantly lower-class) performers. This duality only began to change in the mid-1930s, when Terang Boelan (1937) was released to massive commercial success and revitalized the flailing Indies cinema industry. Directed by Albert Balink and starring Rd. Mochtar and Roekiah, the film drew new audiences and received an international release, earning 200,000 Straits dollars in British Malaya and the Straits Settlement. With their widespread recognition for the film, the cast toured the archipelago as the Terang Boelan Troupe before joining Tan's Film and producing another commercial blockbuster, Fatima (1938). Roekiah, the film's leading lady, thus became the Indies first bankable female star, helping to ensure that individual film actors would gain wide recognition while (inadvertently) requiring that performers would require carefully maintained public personas in order to further develop their popularity.

\section{Theory Application}

\section{Roekiah, the First Grand Dame of Indonesian Cinema}

Born in 1917, Roekiah was the daughter of Mohammad Ali and Ningsih, actors with the Opera Poesi Indra Bangsawan. Though their marriage crossed ethnic lines - Mohammad Ali was of Belitung, while Ningsih was Sundanese they were united in their love of the stage. Roekiah was immersed in the world of acting from a young age, travelling around Java with her parents as they went from troupe to troupe and venue to venue. This lifestyle of constant touring and her lower-class background meant that Roekiah had no time for the formal schooling which could have otherwise been available.

Rather, Roekiah studied acting, observing her parents and their fellow performers, intent on entering the field despite her parents' protests. To satisfy her daughter's desire, in 1924, while the family was with the Opera Rochani, Ningsih agreed to let Roekiah attempt a single performance, after which the seven-yearold would not be allowed on stage again. With this condition, Roekiah went onstage and began to sing - having inherited the vocal talents of her mother - to the great appreciation of the crowd. However, Mohammad Ali was unaware of his daughter's agreement with her mother, and rushed onto the stage and pulled Roekiah aside. The aspiring actress spent the next several days refusing to eat 
until her parents relented and gave their blessings for Roekiah to begin a stage career.

Over the next several years, Roekiah performed regularly with a number of troupes, gaining a reputation as a beautiful and talented songstress. In 1932 she joined the Palestina Opera of Batavia, where she met the man who was to become her husband, Kartolo, a Javanese priyayi several years her elder who wrote and played music for the troupe. Roekiah, aged fifteen at the time of her marriage, later stated that she had not fallen in love with Kartolo on first sight, but rather grew closer to him as she found that his playing complemented her singing well, and that he was skilled in writing songs which worked well with her voice. Their partnership continued on the stage and screen until Roekiah's death.

After several years with the Farokah Troupe, with whom they reached Singapore, Roekiah and Kartolo returned to the Indies in 1936 and decided to stop their acting careers and focus on their two children, a number which would increase to five over the following years. However, with no income, they were not long afterwards in dire financial straits. By this time, the Algemeen Nederlandsch Indisch Filmsyndicaat (ANIF) was casting for the film Terang Boelan, to be directed by Albert Balink and shot by Joshua and Othniel Wong. Roekiah was brought on as the leading lady, portraying Rohaya, while Kartolo received a supporting role as Dullah. The film was an unprecedented success, and set a box office record which would not be broken by a domestic production until Krisis in 1953 (Anwar, 2004).

After filming wrapped and ANIF shut down its fiction film division, Roekiah fell into a depression. Kartolo then took her on a tour of the Indies and Singapore together with the cast of Terang Boelan, billing themselves the Terang Boelan Troupe. This cured Roekiah's depression, and upon returning to Batavia the cast - including Roekiah, Kartolo, Rd Mochtar, and the Wong brothers - was hired by Tan's Film for Fatima (1938), the company's first production since Njai Dasima in 1932. This new film's plot closely followed

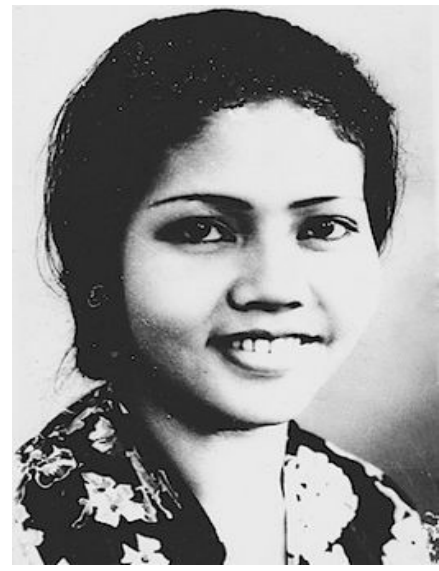

Fig. 1: Roekiah in that of Terang Boelan; both featured Roekiah and Mochtar as lovers who come from an island and succeed in capturing a wanted criminal. Fatima's success mirrored its predecessor's, though on a smaller scale.

For the rest of her feature film career, Roekiah stayed with Tan's, and the studio paid her 150 gulden a month, with another 50 for Kartolo (Imanjaya, 2006); this figure, exorbitant at the time, reflected Roekiah's rising popularity. Over the next two years Roekiah appeared as Mochtar's romantic interest in two further films: Gagak Item (1939) and Siti Akbari (1940). Their partnership was recognized throughout the colony, and they were compared to the on-screen Hollywood couple of Janet Gaynor and Charles Farrell. When Mochtar left the company following a payment dispute, Kartolo asked his friend Ismail Djoemala - a tailor by trade - to become his wife's on-screen partner; Djoemala and Roekiah were paired for four films (Sorga Ka Toedjoe [1940], Roekihati [1940], Poesaka Terpendam [1941], and Koeda Sembrani [1941]) and continued to draw viewers 
in droves, though none of these productions reached the same level of success as Roekiah's first two films.

Her career was cut short by war. In March 1942, the Dutch colonial government capitulated to the Japanese Empire, and during the ensuing three year occupation, domestic cinema ground to a halt; only six shorts are recorded, all propaganda, and only one of those, Ke Seberang (1944), involved Roekiah. Most of Roekiah's time was spent travelling through Java and performing on stage for the Japanese troops. The tight schedule which she was forced to keep gave her little time to rest, and her health began to suffer. She fell ill in February 1945, but the occupation government forced her to travel from Jakarta to Surabaya for a performance. Her health never recovered, and after several months of treatment she died on September 2, 1945 ("Roekiah Meninggal Doenia").

\section{The Path to Fame: Negotiations between Modernity and Tradition}

Roekiah's public persona consisted of two elements, namely the characters she portrayed - which led viewers to attribute the characteristics shown in these roles to the actress - and the public face presented, by herself or others, in other media, including photographs, reviews, and media interviews. Though for the purposes of this discussion these traits have been categorized based on whether they were presented on screen or in other media, it is important to remember that all of these traits were presented contemporaneously, through the different media, and in their interactions offered balances and counterbalances between modernity and tradition which were central to the development of Roekiah's public persona.

In her eight feature-length films, Roekiah frequently portrayed young women who fall in love with young men who are not rich (Rd Mochtar's character in Fatima, Idris, was a fisherman), are kindly and loving, willing to protect them. Her characters spurned advances from rich but immoral men, even when their families preferred the pairing; in Terang Boelan, for instance, Roekiah's character Rohaya rejects her father's demands that she marry Musa, who is (unbeknownst to his fellow villagers) an opium smuggler. In all cases the despicable and immoral acts of her characters' parents' selection are revealed, and Roekiah's characters receive their family's support to marry for love. Even in cases where her characters are not faced with their families' rejection, Roekiah's characters consistently gives consideration to their families' feelings, to the point that Sorga $\mathrm{Ka}$ Toedjoe's Rasminah refused to marry Hoesin (Djoemala) unless her aunt Hadidjah is reunited with her husband first.

Only in two of Roekiah's films, Siti Akbari and Roekihati (both 1940), does the courtship process not take central stage. However, the relationship between the characters portrayed by Roekiah and the male lead remained key to the story. In both instances, the central conflict of these films is not the romantic attraction of two young people, but a young wife's suffering as her husband goes astray. In both films, Roekiah portrays a woman who remains faithful, patiently waiting for her husband to realize that the woman he has left her for (and, in the case of Roekihati, wanted to take as a second wife) is lacking. Never do Roekiah's characters commit adultery, or find replacements for their husbands. Their virtue is, in both instances, rewarded by the character's husband returning, and their relationship continuing more strongly than before.

When these films were released in the late 1930s and early 1940s, marriage for love - considered a European, or "modern", ideal - had begun to gain popular 
approval, while the tradition of parents arranging marriages for their own financial or social benefits (often over their own children's protests), was still practiced, but had received considerable condemnation. However, the idea of a child marrying a person for love over their parents' protests, something perceived as often happening in European culture, was firmly rejected; even though children were allowed to choose their own spouses, parents' blessings were still required. After marriage, women were expected to remain faithful to their husbands no matter what challenges they faced; a woman who was spurned by her husband and began entertaining other men, or abandoned what were considered her household duties, faced social ostracism. Though polygamy was allowed for men (a situation which had, however, begun to be condemned by the general populace), women were expected to remain patiently monogamous. These negotiations of modernity and tradition were reflected in Roekiah's characters, who embraced aspects of European "modernity" with widespread support, but avoided "modern" ideals which were still controversial. As will be seen, this "modern yet not too modern" form of negotiations dominated the construction of Roekiah's public persona, both on screen and in the media.

Beginning with Terang Boelan, Roekiah consistently portrayed women from villages (representative of tradition) rather than cities (representative of modernity), and their personalities are reflective of this origin. The women portrayed by Roekiah are respectful and timid, soft-spoken and deferential to men and their elders. Although they can assert themselves, this is only done rarely, and never in a physical manner; in the face of danger, they are the stereotypical "damsels in distress", needing to be rescued by male characters. This is particularly evident in Sorga Ka Toedjoe. Roekiah's character, Rasminah, is consistently polite, even to people she dislikes intensely, addressing the manipulating and greedy son of a landlord, Parta, as "Tuan" (Sir). Later, she asserts herself by insisting that she can only marry Hoesin after her aunt is reunited with her former husband. However, when she is pursued by Parta and his stooge Doel, she can only flee; Hoesin must fight Parta to ensure her safety.

Such timidity and meekness in Roekiah's characters upheld the patriarchal ideal that a woman should not be brash or outspoken, that women should be deferential to men - even those whom they disliked - owing to their different social stations. The characters' lack of physical assertiveness, and the need for them to be rescued by men, likewise reinforced traditional gender roles; men were obligated to protect women from danger, as they were considered intrinsically weaker and thus less able to defend themselves. The characters reinforced patriarchal constructs, portraying women as the traditional patriarchy in Java expected women to act; this ensured that they were considered positive examples by conservative lower--class viewers, and thus received greater empathy and acceptance. The studios also benefited, as greater success with audiences offered greater commercial performance.

Patriarchal expectations are also present in the employment taken by Roekiah's characters. Her first two characters, Rohaya in Terang Boelan and Fatima in Fatima, are unemployed, staying at home while their husbands or lovers work. Later characters, such as Roekihati in Roekihati and Rasminah in Sorga Ka Toedjoe, take up employment, but in fields considered socially acceptable for women. Rasminah, who goes to Batavia to support her blind aunt, becomes a 
weaver, while Roekihati, who works to support her ailing mother and father, becomes a maid before working as a singer at a restaurant. In the subsequent film Koeda Sembrani, Roekiah's character is again unemployed, though in this case her financial situation is sound as she is a Middle-Eastern princess.

Although the women of the Indies in the 1940s could work, the traditional patriarchal construct limited the fields open to them. Only rarely did women become doctors, engineers, or lawyers. Generally, they were limited to manual labor: sewing, factory work, or farming; women could also become singers many of the colony's most popular vocal artists were women - but there was still the stigma of promiscuity and unladylike behaviour attached to such employment. Significantly, in both of these cases where Roekiah's characters find employment, they do not do so to cover their own living costs, but rather to support sick or disabled family members; they do not look for work when other individuals can support them, but only when nobody could help them or their families. This combination of factors - of "gender-appropriate" jobs and of working only out of necessity - meant that Roekiah's characters were in line with the patriarchal expectations of women in the workforce; again, by not challenging expectations, she and the studio were able to ensure that the lower-class audiences they targeted would not reject the story or actress, thus giving them a greater chance at popular and financial success.

Off the screen, Roekiah's identity as a film actress and keroncong singer was central to the construction of her public persona. As a keroncong singer and film actress, Roekiah was in a profession which embraced modernity in technical aspects. The contents of songs, the melodies used, the dialogue spoken, the recording technology used to spread singers' and actresses' talents throughout the colony - all these modern aspects received wide praise, and similarity to older media such as the stage was condemned by critics. However, in participating in such a medium, Roekiah also invited the possibility of social stigma. Since the beginning of the stage, actresses in the Indies were often seen as salacious and promiscuous; keroncong singers were viewed with similar disdain. Though film had become increasingly popular, by continuously appearing in romantic roles with men who were not her husband (first Rd Mochtar,

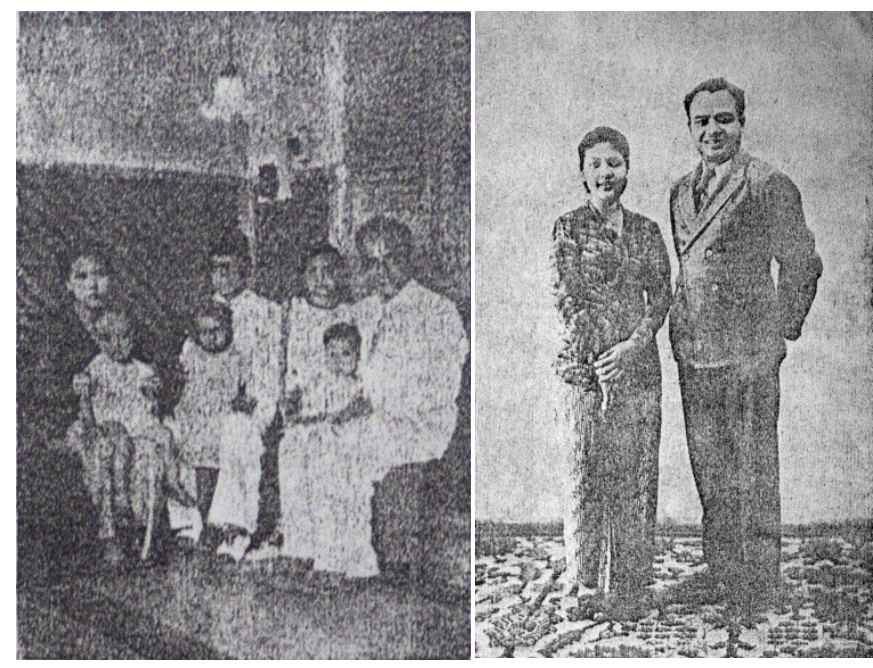

Fig. 2: Emphasis of family roles in media depictions of Roekiah and later Djoemala), Roekiah would have been open to similar accusations; however, none were made in the media.

The reason for this can be found in media coverage, which did not show her relations with her co-stars, but rather focused on her relationship with Kartolo and 
her role as a mother. For readers of the print media, Roekiah's family life was never far from the forefront. Photographs of the artist (Fig. 2), when not showing her on her own or in a role, showed her smiling happily with her husband (right, which accompanied an article titled "Film dan Radio") or with her five children (left, from "Riwayat Roekiah-Kartolo"). In interviews, meanwhile, she presented herself as an attentive mother who was submissive to her husband; both were expected of contemporary women. In Pertjatoeran Doenia dan Film, Kamadjaja described interviewing Roekiah:

[After being escorted by Kartolo,] I was introduced to Roekiah. As a timid person does, she shook my hand while nodding sweetly. It was true; Roekiah's smile could light up a man's heart. But while smiling, looking at me, she glanced at her husband, Mas Kartolo, a sign she was a wife who truly loved her husband. ... [After the interview], Mas Kartolo stayed behind to play billiards, while Roekiah went home to prepare her household needs and care for her children (Kamadjaja, 1941: 18).

This sidelong glance, described as a sign that the actress truly loved Kartolo, would have allowed Roekiah to judge whether or not her husband approved of her answering the other man's questions. Kartolo, though supportive of his wife's career, for his part asserted a degree of control in public; it was he who escorted Kamadjaja to the interview (and, thus, could judge whether or not the journalist was trustworthy). He also chose Djoemala to replace $\mathrm{Rd}$ Mochtar as Roekiah's love interest on screen,

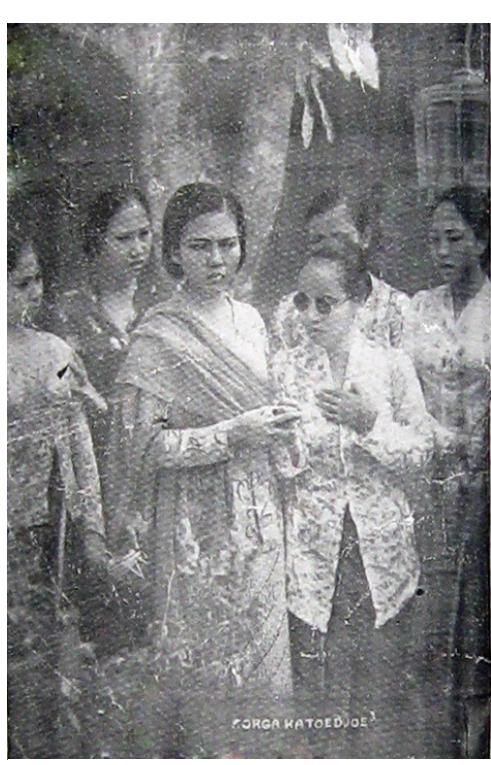

Fig. 4: Roekiah (left) in a promotional still from

Sorga Ka Toedjoe, showing her characteristic presumably after deciding that the tailor could be trusted in romantic scenes. This assertion of control likely relieved any tensions created by the disparity of Kartolo and Roekiah's wages; though Roekiah earned

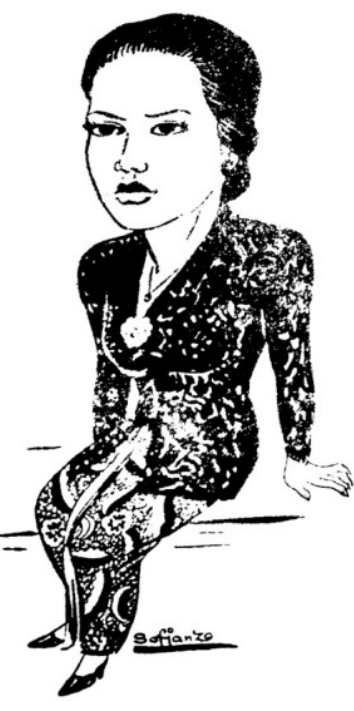

Fig. 3: Sketch of Roekiah, described by Kamadjaja as showing her timid nature

more money, publicly Kartolo remained the dominant decision maker, and thus upheld traditional gender roles.

Roekiah's publicly submissive and timid nature was frequently subject to commentary. As such, journalists participated in the construction of her public persona. Kamadjaja, in his interview, emphasized her meekness: he described her as softspoken, used the term "maloe-maloe" (timid) several times, and found her upon their first 
meeting to be "almost as if she were hiding". An accompanying sketch, by the artist Sofianzo (Fig. 3), was labelled "Her face shows her timidity, sometimes [it's] almost as if she is frightened." In another instance, a reviewer for the Bataviaasch Nieuwsblad emphasized her "demure" demeanour in a review of the film Gagak Item ("Filmaankondiging Cinema Palace").

This public exhibition of timidity and meekness, as well as the continued press coverage of this personality, allowed Roekiah to be presented as a shrinking violet, upholding the patriarchal ideal that a woman should not be brash or outspoken. Through her publicly meek demeanour and regular depictions with her family, Roekiah set herself apart from fellow actresses such as Ratna Asmara, whose public personas significantly deviated from those traditionally expected of women. By publicly embracing the traditional, patriarchal construct of how a woman should act, even though she was an actress in the most modern medium available and a singer of a modern music genre, Roekiah ensured that she would not alienate the conservative lower- and middle-class viewers. This guaranteed her acceptance by audiences, as she remained true to traditional values despite the intrinsic modernity of movie stardom.

Roekiah's physical appearance complemented her personality, and thus assisted her in developing a successful public persona. Her clothing, both on stage and in public, was inspired by traditional attire; she avoided the luxurious gowns borne by Hollywood celebrities. Generally, she wore simple V-neck blouses (often with a floral pattern), sometimes with a shawl around her shoulder, and a batik sarong (Fig. 4). Her hair was usually tied in a knot, or otherwise worn short. Unlike Fifi Young, who wore a frilly and revealing dress when promoting her film Zoebaida, Roekiah rarely bared her shoulder or legs, thus showing a degree of modesty which resonated with conservative audiences. This did not detract from her frequently remarked upon beauty, but rather added to it. Roekiah, in her appearance as with her actions, embodied traditional patriarchal expectations of a woman: that she be beautiful, yet modest; fashionable, but not wasteful.

It must be emphasized that the above elements were mutually influential; the public face presented by Roekiah had an impact on the characters written for her, while the roles she took influenced how she presented herself and was presented to the public. For instance, her demure characters helped make demureness a desirable public trait, while her public appearance as a submissive and humble wife correlated with humble and submissive female characters being written for her. Had Roekiah's public persona been one of a self-reliant and daring woman, a modern woman of the city, the viewing public would not have accepted her portrayal of simple village women such as Roekihati or Rasminah.

In the negotiation between modernity and tradition, Roekiah's public persona put greater emphasis on traditional expectations of women. On screen, Roekiah's characters married for love and rejected individuals deemed unsuitable, at times over their parents' protests, but in all cases her characters remained faithful to their chosen men and eventually received their parents' blessings. Though her characters may have found work outside of the household, these were never in male-dominant fields, but in fields considered by the patriarchy to be suitable for women. Roekiah's public presentation, meanwhile, focused on her talent and beauty. Though she was a keroncong singer and actress - professions popularly perceived as being full of salacious women - Roekiah's morality was 
never questioned, for her public persona emphasized her relationship with her husband and their children.

This emphasis on tradition ensured both Roekiah's performances and public persona had greater resonance with the majority of filmgoers, who were of the lower and lower-middle classes and upheld traditional gender roles. She did not explicitly challenge patriarchal constructs, instead conforming to them in a way that allowed audiences to consider her a good representative of "modern yet not too modern" women. Those modern aspects which she embraced, including her chosen medium and genre, had already been internalized within Indies popular culture and thus had wide acceptance. As such, Roekiah's public persona was a relatively conservative one, particularly in comparison to fellow artists such as Fifi Young (who, in her first two roles, depicted women who married men without their parents' approval), Hadidjah (whose screen debut was as a self-reliant jungle princess in Alang-Alang), and Ratna Asmara (whose first film role was as a nurse who explicitly rejected tradition in Kartinah, and was haughty in public). Her conservative public persona enabled Roekiah to gain greater popularity than her contemporaries, and thus helped cement her reputation as the first grand dame of Indonesian cinema.

\section{Conclusion}

The cinema of the Dutch East Indies developed as a dualistic entity, promoting the modern technological marvel of film while simultaneously concretizing traditional biases in the arts and society. Though some of the more traditional aspects, such as the emphasis on roles over actors, faded over time, the colonial film industry never abandoned these cultural roots. It continued embody a clear duality within a society which was itself negotiating a path between tradition and modernity.

In this context, Roekiah emerged as the first bankable leading lady of the Indies. Trained as a stage actress, she and her husband Kartolo embraced film upon their entry and massive success in the industry in 1937. Over the next five years, before the Japanese occupation drained her of her health, Roekiah started in seven further films, acting as the romantic interest to two different men - neither of whom was her husband - and drawing thousands of fans. She earned a significant income, greater than her husband's, and her every action was the subject of the movie-going public's curiosity.

To mediate the non-traditional position in which she found herself, through her characters Roekiah reflected a blend of tradition and modernity, a fusion which could be accepted by the patriarchal society of the Indies. She wore semitraditional, feminine clothing, and portrayed women who were polite and demure in facing men and their families. Her characters became housewives and weavers, taking positions which would not challenge male authority. Even when she was not acting on film, Roekiah presented a public persona - a separate role, as it were - serving as a demure wife who provided her husband with many children and remained faithful and submissive. Roekiah's public persona embodied both a modern ideal of entertainment, as she sang keroncong and acted in films, but also appeared unthreatening to the traditional social hierarchy. This public persona helped her become the first grand dame of Indonesian cinema, popular with audiences of all creeds, ages, and backgrounds, and surpass her contemporaries. 


\section{References}

Anonymous. (1932). Njai dasima advertisement: De indische courant. Retrieved on April 24, 2015, from http://www.delpher.nl/nl/kranten/view?identifier=ddd:010283820:mpeg21:a $0072 \&$ coll $=$ ddd

Anonymous. (1939). Filmaankondiging cinema palace: Gagak item. Bataviaasch Nieuwsblad. Retrieved on May 13, 2015, from http://resolver.kb.nl/resolve?urn=ddd:011123019:mpeg21:a0235

Anonymous. (1945). Roekiah meninggal doenia. Tjahaja, 2.

Anonymous. (1969). Miss Roekiah: Artis telada. Moderna, 1(6), 30-34.

Anonymous. (1977). Miss Roekiah: Perintis bintang film Indonesia. Keluarga, 4, 4-7.

Anonymous. (1982). Roekiah Kartolo: Primadona opera 'Palestina' dan pelopor dunia layar perak. Berita Minggu Film, 5(9).

Anwar, R. (2004). Sejarah kecil "petite histoire" Indonesia, 2. Jakarta: Kompas.

Biran, M. Y. (1979). Apa siapa orang film Indonesia 1926-1978. Jakarta: Sinematek Indonesia.

Biran, M. Y. (2009). Sejarah film 1900-1950: Bikin film di Jawa. Jakarta: Komunitas Bamboo working with the Jakarta Art Council.

Dewantara, K. H. (1941). Film dan radio. Pertjatoeran doenia dan film, 1(1), 7-8.

Djokdjasche causerieen. (1926). De indische courant. Retrieved on April 25, 2015 , from http://resolver.kb.nl/resolve?urn=ddd:010278153:mpeg21:a0124

Imanjaya, E. (2006). A to z about Indonesian film. Bandung: Mizan.

Imong, W. (1941). Riwayat roekiah-kartolo. Pertjatoeran doenia dan film, 1(2), $20-22$.

Kamadjaja. (1941). Studio reporter. Pertjatoeran doenia dan film, 1(4), 18-19.

Kwee, T. H. (1929). Film njaie dasima, productie dari tan's film company. Panorama, 3(153), 1199-1201.

Kwee, T. H. (1930). Pemandangan film Melati van Agam: Productie paling baroe dari Tan's Film Company. Panorama, 4(181), 27-28.

Suryadinata, L. (1995). Prominent Indonesian Chinese: Biographical sketches. Singapore: Institute of Southeast Asian Studies.

Tal-Or, N. \& Papirman, Y. (2007). The fundamental attribution error in attributing fictional figures' characteristics to the actors. Media psychology, 9(2), 33145. Retrieved on April 8, 2015, from http://www.allacademic.com/meta/p13476_index.html 